\title{
PERAN PENDIDIKAN POLITIK DALAM MEMBANGUN SIKAP DEMOKRATIS SISWA MELALUI ORGANISASI SISWA INTRA SEKOLAH DI SMP NEGERI 22 SEMARANG
}

\section{Farid Shalihudin, Fredy Hermanto ${ }^{\bowtie}$}

Prodi Pendidikan Ilmu Pengetahuan Sosial, Fakultas Ilmu Sosial, Universitas Negeri Semarang, Indonesia

\begin{tabular}{l}
\hline Info Artikel \\
\hline Sejarah Artikel: \\
Disubmit: Januari 2021 \\
Direvisi: Februari 2021 \\
Diterima: Maret 2021 \\
\hline Keywords: \\
Role, Political Education, \\
Democratic Attitude, \\
Active Participation \\
\hline
\end{tabular}

\begin{abstract}
Abstrak
Penelitian ini bertujuan untuk mengetahui upaya sekolah dalam membangun sikap demokratis siswa melalui OSIS di SMP Negeri 22 Semarang. Hasil penelitian menunjukkan bahwa sekolah berupaya dalam memberikan pemahaman pendidikan politik. Pengurus OSIS sudah mengimplementasikan pemahaman pendidikan politik yang diberikan sekolah serta dapat diketahui melalui aktivitasnya. Implementasi pemahaman pendidikan politik dalam membangun sikap demokratis masih ada yang belum maksimal. Partisipasi aktif pengurus OSIS meliputi; (1) pengambilan keputusan, (2) pelaksanaan, (3) pengambilan manfaat, (4) evaluasi, dan (5) sikap sosial. Sedangkan hasil analisis peran pendidikan politik dalam membangun sikap demokratis siswa menunjukkan bahwa pembinaan berupaya dalam pembentukan kesadaran pengurus OSIS, motivasi berperan dalam penyelesaian masalah, dan evaluasi berperan dalam mengetahui kekurangan pengurus OSIS.
\end{abstract}

\begin{abstract}
This study aims to determine the school's efforts in building student democratic attitudes through OSIS at SMP Negeri 22 Semarang. The results showed that schools made an effort to provide an understanding of political education. The OSIS management has implemented the understanding of political education provided by the school and can be seen through its activities. The implementation of understanding political education in building democratic attitudes is still not optimal. The active participation of the OSIS management includes; (1) decision making, (2) implementation, (3) taking benefits, (4) evaluation, and (5) social attitudes. Meanwhile, the results of the analysis of the role of political education in building student democratic attitudes show that coaching seeks to build the awareness of the student council officials, motivation plays a role in problem solving, and evaluation plays a role in knowing the shortcomings of the student council administrators.
\end{abstract}

(C) 2021 Universitas Negeri Semarang

\begin{tabular}{lc}
\hline Alamat korespondensi: & E-ISSN 2685-4929 \\
Gedung C1, Lantai 1, FIS UNNES & \\
Kampus Sekaran, Gunungpati, Semarang, 50229 & \\
Email: fredy@mail.unnes.ac.id & \\
\hline
\end{tabular}




\section{PENDAHULUAN}

Pendidikan nasional berfungsi mengembangkan kemampuan dan membentuk watak serta peradaban bangsa yang bermartabat dalam rangka mencerdaskan kehidupan bangsa, bertujuan untuk berkembangnya potensi peserta didik agar menjadi manusia yang beriman dan bertakwa kepada Tuhan Yang Maha Esa, berakhlak mulia, sehat, berilmu, cakap, kreatif, mandiri, dan menjadi warga negara yang demokratis serta bertanggung jawab (UndangUndang RI Nomor 20 Tahun 2003). Pendidikan politik merupakan upaya pendidikan yang disengaja dan sistematis untuk membentuk individu agar mampu menjadi partisipan yang bertanggung jawab secara etis/moral dalam pencapaian tujuan politik (Kartini Kartono, 1996: 64). Tujuan pendidikan politik adalah memberikan sumbangan besar bagi proses demokrasi yang semakin maju dari semua individu (rakyat) dan masyarakat/struktur kemasyarakatannya dan dengan prinsip-prinsip realistik, lebih manusiawi dan berlandaskan hukum formal dalam menggalang komunikasi politik yang modern (Kartini Kartono, 1996: 57).

Warga negara yang demokratis dapat dibentuk melalui pendidikan politik. Pendidikan politik dapat diperoleh melalui organisasi kesiswaan. Dalam organisasi kesiswaan, anggota organisasi akan berlatih untuk berpikir kritis, berpartisipasi secara aktif, bertanggung jawab, dan belajar untuk hidup bermasyarakat, berbangsa dan bernegara. Pembelajaran dalam organisasi tersebut merupakan wujud dari pembentukan manusia yang demokratis yaitu dapat menjadi manusia yang dapat mengutamakan persamaan hak dan kewajiban. Untuk mewujudkan persamaan hak dan kewajiban tersebut, anggota organisasi seharusnya dapat berperan aktif yang ditunjukkan melalui sikap kritis dan berlaku adil terhadap sesama anggota organisasi.

Ilmu Pengetahuan Sosial (IPS) di SMP dan MTs di Indonesia bertujuan untuk mengembangkan kesadaran serta kepedulian terhadap masyarakat dan lingkungannya (Supardi, 2011: 185). Muhammad Numan Somantri (2001: 44) juga mendefinisikan tujuan Ilmu Pengetahuan Sosial untuk tingkat sekolah, yaitu 1) menekankan pada tumbuhnya nilai-nilai kewarganegaraan, moral ideologi negara, dan agama, 2) menekankan pada isi dan metode berpikir ilmu sosial, dan 3) menekankan pada reflective inquiry. Dapat disimpulkan bahwa Ilmu Pengetahuan Sosial bertujuan untuk mengembangkan kesadaran dan kepedulian masyarakat serta menekankan tumbuhnya nilainilai kewarganegaraan, ideologi negara, dan agama serta menekankan metode berpikir ilmu sosial. Menurut peneliti, dengan menguasai konsepkonsep Ilmu Pengetahuan Sosial dapat menambah wawasan yang lebih luas dan mendalam tentang pendidikan politik dalam Organisasi Siswa Intra Sekolah di dalam sekolah yang merupakan lingkungan sosial bagi siswa untuk membentuk sikap demokratis siswa. Selain itu, melalui Organisasi Siswa Intra Sekolah siswa juga mendapatkan pendidikan politik yang merupakan bagian dari ilmu sosial yang mana tidak di dapatkan melalui pembelajaran di dalam kelas.

Berdasarkan observasi awal dapat diperoleh keterangan dari Pembina OSIS bahwa OSIS berperan penting sebagai salah satu sumber pendidikan politik bagi siswa. Hasil observasi menunjukkan bahwa pemilihan ketua OSIS di SMPN 22 Semarang melalui voting atau pemilihan suara terbanyak. Suara terbanyak yang pertama akan terpilih sebagai ketua, suara terbanyak kedua sebagai wakil ketua, dan suara terbanyak ketiga sebagai kepala bidang ataupun sebagai pengurus inti. Setelah terpilih ketua yang baru, pengurus OSIS melaksanakan seleksi penerimaan anggota baru yang dilaksanakan setiap tahun sekali. Ketika sudah terbentuk struktur kepengurusan OSIS yang baru, pengurus OSIS melaksanakan kegiatan Latihan Dasar Kepemimpinan yang kegiatannya disusun oleh beberapa guru sebagai pembina OSIS dengan maksud melatih kepemimpinan siswa sebagai pengurus OSIS. Kegiatan pemilihan ketua serta anggota OSIS dan latihan dasar kepemimpinan tersebut merupakan kegiatan yang menunjang siswa sebagai pengurus OSIS untuk memperoleh pendidikan politik di lingkungan sekolah. Pemilihan ketua serta anggota OSIS diharapkan dapat membantu siswa lebih mengerti bagaimana sistem voting dan musyawarah yang biasa dilaksanakan masyarakat Indonesia 
sebagai negara demokrasi. Berdasarkan latar belakang tersebut, peneliti berfokus dalam mengetahui: (1) upaya sekolah dalam membangun sikap demokratis siswa melalui OSIS, (2) upaya sekolah dalam membangun partisipasi aktif siswa melalui OSIS, dna (3) peran pendidikan politik dalam membangun sikap demokratis siswa melalui OSIS.

\section{METODE}

Penelitian ini merupakan penelitian kualitatif, yaitu penelitian yang digunakan untuk meneliti pada kondisi obyek alamiah, teknik pengumpulan data dilakukan secara triangulasi, analisis data bersifat induktif, dan hasil penelitian lebih menekankan makna daripada generalisasi (Sugiyono, 2016: 1). Lokasi penelitian dilakukan di SMP Negeri 22 Semarang yang terletak di J1. Raya Manyaran - Gunungpati, Rt 01/Rw 01, Nongkosawit, Kecamatan Gunungpati, Kota Semarang.

Fokus penelitian ini adalah pada upaya sekolah dalam memberikan pemahaman nilai demokratis, partisipasi aktif siswa, sikap sosial siswa, dan peran pendidikan politik dalam membangun sikap demokratis siswa melalui OSIS. Sumber data dalam penelitian ini dibedakan menjadi 2 yaitu sumber data primer dan sumber data sekunder (Sugiyono, 2017: 308). Sumber data primer dalam penelitian ini diperoleh dengan melaksanakan wawancara kepada Kepala Sekolah, Pembina OSIS, dan Pengurus OSIS SMP Negeri 22 Semarang. Sedangkan data sekunder dalam penelitian ini adalah arsip sekolah, arsip OSIS, dan foto dokumentasi. Teknik pengumpulan data dilakukan dengan teknik triangulasi. Pada penelitian ini menggunakan triangulasi sumber. Selain itu, peneliti melakukan wawaracara dan pengumpulan dokumentasi. Wawancara dilakukan secara langsung dengan pengurus OSIS sebagai informan utama serta kepala sekolah dan Pembina OSIS sebagai informan pendukung. Teknik analisis data dalam penelitian ini meliputi pengumpulan data, reduksi data, penyajian data dan penarikan simpulan.

\section{HASIL DAN PEMBAHASAN}

Penelitian ini dilaksanakan di SMP Negeri 22 Semarang. SMP Negeri 22 Semarang terletak di J1. Raya Manyaran - Gunungpati, RT 01/RW 01, Nongkosawit, Kecamatan Gunungpati, Kota Semarang, Jawa Tengah. Sekolah ini memiliki luas tanah $11.204 \mathrm{~m} 2$ dan luas bangunan 3.455 m2. Kegiatan Belajar Mengajar di SMP Negeri 22 Semarang dilaksanakan selama 5 hari kerja, mulai dari Senin sampai Jum'at. Hari Senin hingga Kamis pembelajaran dimulai pukul 07.00 hingga pukul 16.00 WIB. Hari Jum'at kegiatan pembelajaran dimulai pukul 07.00 hingga pukul 11.00 WIB. Namun semenjak adanya Pandemi COVID-19 ada perubahan seperti jam belajar mengajar serta jam istirahat. Kegiatan Belajar Mengajar (KBM) untuk sementara belajar secara dalam jaringan (online) dari rumah masingmasing. Sekolah hanya dihadiri oleh guru dan karyawan dengan menerapkan sistem Work from Home (WFH) dan Work from Office (WFO). Organisasi Siswa Intra Sekolah (OSIS) SMP Negeri 22 Semarang adalah organisasi yang bersifat intra sekolah dan merupakan organisasi kesiswaan yang sah di SMP Negeri 22 Semarang. Hal tersebut dapat dilihat melalui Keputusan Kepala SMP Negeri 22 Semarang Nomor. 422.1/627/2019 tentang Susunan Perwakilan Kelas, Pengurus OSIS, dan Pembina OSIS.

\section{Upaya Sekolah dalam Membangun Sikap Demokratis Siswa melalui OSIS}

Upaya sekolah dalam membangun sikap demokratis siswa dapat dilihat melalui beberapa indikator yang berpedoman pada pendapat nilai demokratis menurut Zamroni (2001) antara lain: (1) toleransi; (2) kebebasan mengemukakan pendapat; (3) menghormati perbedaan pendapat; (4) memahami keanekaragaman; (5) terbuka dan komunikasi; (6) menjunjung tinggi nilai dan martabat kemanusiaan; (7) percaya diri; (8) tidak menggantungkan pada orang lain; (9) saling menghargai; (10) mampu mengekang diri; dan (11) kebersamaan dan keseimbangan.

SMP Negeri 22 Semarang memiliki keanekaragaman mulai dari siswa hingga guru. Keanekaragaman yang ada di sekolah dapat dilihat dari beberapa jumlah agama yang dianut oleh siswa di SMP Negeri 22 Semarang. 
Keanekaragaman agama berdasarkan hasil penelitian antara lain Islam, Kristen, Katholik, dan Hindu. Toleransi dapat ditunjukkan melalui sikap saling menghargai pendapat terutama saat melaksanakan musyawarah. Selain itu, pengurus OSIS juga menunjukkan keterlibatannya dalam kegiatan keagamaan. Kegiatan keagamaan bukan hanya untuk satu agama saja, melainkan tetap memfasilitasi seluruh agama yang dianut warga sekolah. Hal tersebut sesuai dengan pendapat yang dikemukakan oleh Ahmad (2018: 31) toleransi merupakan sikap terbuka serta menghormati perbedaan.

OSIS dalam melaksanakan kegiatan tidak dapat terlepas dari adanya pendapat pengurus. Sangat dimungkinkan apabila pendapat antar pengurus dapat berbeda-beda. Berdasarkan hasil penelitian dapat diketahui bahwa kebebasan mengemukakan pendapat oleh pengurus OSIS. Hasil penelitian menunjukkan bahwa sekolah dapat terbuka dalam menerima aspirasi siswa melalui pengurus OSIS serta penyediaan kotak saran untuk seluruh warga sekolah. Temuan tersebut sesuai dengan pendapat dari Tukiran (2015: 140) kebebasan berpendapat merupakan sebuah hak bagi warga negara yang wajib dijamin dengan undang-undang dalam sebuah sistem politik demokrasi. selain itu, pengurus OSIS juga telah menggunakan haknya untuk menyampaikan pendapat kepada sekolah walaupun belum maksimal karena hanya beberapa pengurus saja yang menyampaikan pendapatnya kepada sekolah.

Penyampaian pendapat dalam OSIS tentunya tidak dapat memaksakan semua orang dalam penyampaian pendapat. Oleh karena itu, perlu adanya sikap saling menghormati perbedaan pendapat dalam OSIS. Hasil penelitian menunjukkan bahwa pengurus OSIS dapat menunjukkan sikap saling menghormati perbedaan pendapat yang dilihat dari sikap pengurus OSIS dalam melaksanakan musyawarah selama ini tidak pernah terjadi konflik karena perbedaan pendapat. Musyawarah tetap dilaksanakan dalam bertukar pikiran antar pengurus. Seluruh pendapat tetap di terima oleh pemimpin diskusi serta seluruh pengurus OSIS. Melalui musyawarah, pengurus OSIS dapat terbiasa dalam menghormati perbedaan. Temuan tersebut sesuai dengan pendapat dari Hamdi
(2019: 108) menghormati perbedaan pendapat merupakan sikap dan perilaku seseorang dalam memberikan kesempatan kepada orang lain untuk mengungkapkan ide atau gagasannya.

SMP N 22 Semarang memiliki keanekaragaman agama, antara lain Islam, Kristen, Katholik, dan Hindu. Hasil penelitian dapat menunjukkan bahwa pengurus OSIS dapat saling menghormati keanekaragaman dan tidak pernah ada konflik karena keanekaragaman yang ada. Hal tersebut dapat diketahui melalui keterlibatan pengurus OSIS dalam kegiatan keagamaan di sekolah. Kegiatan keagamaan tersebut dapat memfasilitasi seluruh agama yang dianut oleh warga sekolah. Temuan tersebut sesuai dengan pendapat dari Hamdi (2019: 109) memahami keanekaragaman merupakan upaya untuk memberikan pemahaman bahwa kita hidup menjadi warga negara yang memiliki banyak kultur budaya serta agama.

Komunikasi dan keterbukaan antara sekolah dengan pengurus OSIS merupakan hal yang penting dalam keberlangsungan organisasi. Komunikasi dapat berjalan maksimal apabila terdapat keterbukaan antara sekolah dengan pengurus OSIS. Hal tersebut dapat diupayakan oleh sekolah sebagai peran dari pembinaan kesiswaan kepada sekolah. Hasil penelitian menunjukkan bahwa sekolah memberikan informasi dan menerima informasi terkait dengan kesiswaan melalui pengurus OSIS. Sekolah juga menunjukkan keterbukaannya dengan pengadaan kotak saran yang dapat diisi oleh seluruh warga sekolah yang dapat menjadi salah satu bahan evaluasi. Pengurus OSIS juga menunjukkan keterbukaannya dengan menyampaikan perkembangan organisasi secara berkala terutama pada saat sebelum dan setelah kegiatan OSIS berlangsung. Selain itu, komunikasi antara sekolah dengan pengurus OSIS selama ini dapat berjalan dengan baik. Temuan tersebut sesuai dengan pendapat dari Hamdi (2019: 110) terbuka dalam komunikasi merupakan proses penyampaian informasi secara terbuka dari individu kepada individu lain secara terbuka dan tanpa adanya tekanan serta saling mengungkapkan pendapat atau ide.

Menjunjung tinggi nilai dan martabat kemanusiaan dapat diartikan sebagai sikap saling menghargai atau saling menghormati. 
Berdasarkan hasil penelitian, sekolah berupaya untuk memberikan contoh sikap santun kepada orang lain dengan mengajak pengurus OSIS untuk ikut menyambut tamu. Hal tersebut sebagai salah satu pembiasaan kepada pengurus OSIS untuk dapat saling menghormati dengan orang yang baru dikenal. Sekolah juga berupaya untuk memberikan pemahaman sopan santun dalam berbahasa. Temuan tersebut sesuai dengan pendapat Hamdi (2019: 111) menjunjung tinggi harkat dan martabat manusia merupakan menjunjung tinggi hak-hak manusia, menghargai atas kesamaan hak dan derajat, mengemban sikap saling mencintai sesama manusia, tenggang rasa, serta menjunjung tinggi nilai-nilai kemanusiaan.

Percaya diri penting dimiliki oleh pengurus OSIS. Hal tersebut bertujuan untuk mengurangi sikap selalu bergantung kepada orang lain. OSIS juga berperan dalam menumbuhkan sikap percaya diri. Melalui kegiatan organisasi, pengurus OSIS dapat terbiasa dalam melatih dirinya untuk mempunyai sikap percaya diri. Hasil penelitian menunjukkan bahwa Sekolah melalui Pembina OSIS memberikan motivasi untuk lebih percaya diri terutama dalam menyampaikan pendapat atau berbicara di depan umum. Dalam musyawarah, masih ada beberapa pengurus yang pasif oleh karena itu, motivasi dari Pembina OSIS sangat berperan supaya seluruh pengurus OSIS dapat menyampaikan secara maksimal. Temuan tersebut sesuai dengan pendapat Lauster (2002: 2) percaya diri merupakan suatu sikap atau keyakinan atas kemampuan diri sendiri.

Sikap mandiri sama halnya dengan tidak menggantungkan pada orang lain. Hasil penelitian menunjukkan bahwa sekolah telah berupaya dalam menumbuhkan sikap mandiri kepada pengurus OSIS. Hal tersebut dapat diketahui melalui Latihan Dasar Kepemimpinan (LDK) OSIS yang dilaksanakan setiap tahun. Faktanya memang pada saat kegiatan pengurus OSIS tidak selalu di dampingi oleh sekolah. Sekolah hanya berperan dalam persiapan sebelum kegiatan dan evaluasi setelah kegiatan. Temuan tersebut sesuai dengan pendapat dari Hartatik (2014: 45) beberapa nilai kemandirian adalah tidak menggantungkan diri pada orang lain, percaya pada diri sendiri, tidak merepotkan dan merugikan orang lain, berusaha mencukupi kebutuhannya sendiri dengan semangat kerja dan mengembangkan diri.

Setiap orang tidak dapat memaksakan kehendak untuk dapat diterima orang lain. Terutama dalam bermusyawarah harus dapat menerima pendapat orang lain. Hasil penelitian menunjukkan bahwa sekolah berupaya memberikan arahan kepada pengurus OSIS untuk dapat saling menghargai. Sekolah melalui Pembina OSIS menekankan bahwa setiap pengurus tidak boleh membedabedakan orang lain karena tujuannya sama yaitu belajar berorganisasi. Dalam implementasinya selama ini pengurus OSIS juga tidak pernah ada masalah yang berhubungan dengan perbedaan pendapat. Pengurus OSIS dapat saling mendengarkan dan menerima pendapat antar pengurus selama musyawarah. Temuan tersebut sesuai dengan pendapat dari Poerwadarminta (2007: 406) saling menghargai yaitu setiap orang harus menghormati, mengindahkan, memuliakan, dan menjunjung tinggi pendapat dan keyakinan orang lain.

Mengekang diri dapat diartikan sebagai mampu dalam mengutamakan kepentingan umum terlebih dahulu daripada kepentingan pribadi. Hasil penelitian menunjukkan bahwa pengurus OSIS sudah memiliki kesadaran akan tanggung jawabnya masing-masing. Artinya mereka dapat memilih prioritas tanggung jawab yang sudah diberikan daripada urusan pribadi. Temuan tersebut sesuai dengan pendapat dari Hamdi (2009: 113) dalam demokrasi mengekang diri dapat diartikan sebagai sikap menahan diri untuk bertindak demi kepentingan pribadi dan mengutamakan kepentingan umum. Budaya bermusyawarah juga membiasakan pengurus OSIS untuk lebih berhati-hati dalam berbicara dengan orang lain supaya perkataannya tidak menyinggung. Temuan tersebut juga sesuai dengan pendapat Sumarsono (2017: 260) seseorang yang dapat mengekang diri pasti berperilaku halus, sopan dan bersikap tenggang rasa terhadap orang lain.

Hasil penelitian menunjukkan bahwa sekolah telah berupaya memberikan pemahaman tentang pentingnya kebersamaan melalui kegiatan Latihan Dasar Kepemimpinan (LDK). Kegiatan tersebut salah satunya terkait dengan kebersamaan antar pengurus. Pengurus OSIS 
juga menunjukkan kebersamaannya melalui makan bersama dan bermain bersama dengan tujuan memupuk rasa kekeluargaan dan saling mengenal lebih dekat pribadi antar pengurus. Selain itu, pengurus OSIS menunjukkan rasa solidaritasnya dengan saling menjenguk ketika ada teman atau keluarga yang sedang sakit atau tertimpa musibah. Temuan tersebut sesuai dengan Hamdi (2019: 113) demokrasi menuntut manusia untuk mengembangkan kedudukannya sebagai makhluk sosial, seperti memecahkan masalah secara bersama atau melakukan kegiatan secara bersama-sama demi kesejahteraan bersama. Pengurus OSIS juga telah menjalankan tanggung jawabnya sesuai dengan tugas dan perannya masing-masing. Sejak awal periode kepengurusan, pengurus OSIS telah mendapat peran masing-masing sesuai dengan bidangnya. Hal tersebut menunjukkan bahwa sekolah telah berupaya dalam memberikan keseimbangan dalam OSIS dengan memberikan tugas dan peran serta pengurus OSIS telah mengimplementasikan keseimbangan dalam organisasi dengan menjalankan tugas dan perannya sesuai bidang masingmasing.

\section{Upaya Sekolah dalam Membangun Partisipasi Aktif Siswa melalui OSIS}

Pemahaman dari tujuan pendidikan politik tersebut dapat di aplikasikan di lingkungan sekolah dengan ikut berpartisipasi aktif melalui organisasi kesiswaan, dalam hal ini adalah OSIS SMP Negeri 22 Semarang. Indikator terkait dengan pembahasan ini berpedoman pada pendapat menurut Siti (2011: 61), antara lain: (1) partisipasi aktif dalam pengambilan keputusan; (2) partisipasi aktif dalam pelaksanaan; (3) partisipasi aktif dalam pengambilan manfaat; dan (4) partisipasi aktif dalam evaluasi.

Hasil penelitian terkait dengan pengambilan keputusan yang dilaksanakan pengurus OSIS menunjukkan bahwa partisipasinya cukup baik. Partisipasi aktif dalam pengambilan keputusan baik karena faktor dari motivasi yang disampaikan. Namun, tidak seluruh pengurus OSIS dapat berpartisipasi secara aktif dalam pengambilan keputusan. Siswa kelas 7 sebagai pengurus baru cenderung lebih pasif. Terkait dengan perencanaan program kerja, hasil penelitian menunjukkan bahwa partisipasi aktif pengurus OSIS baik. Perencanaan program kerja dilaksanakan setiap tahun sekali melalui musyawarah antara sekolah dengan pengurus OSIS. Antusias pengurus OSIS dapat dilihat dari pelaksanaan musyawarah bersama terlebih dahulu dari seluruh pengurus OSIS sebelum melaksanakan musyawarah dengan kepala sekolah dan pembina OSIS. Temuan tersebut sesuai dengan Siti (2011: 61) partisipasi dalam pengambilan keputusan berkaitan dengan masyarakat dengan gagasan atau ide yang menyangkut kepentingan bersama.

Hasil penelitian terkait dengan partisipasi aktif siswa sebagai warga sekolah SMP Negeri 22 Semarang dalam pemilihan ketua dan wakil ketua OSIS menunjukkan bahwa pemilihan ketua dan wakil ketua OSIS melibatkan seluruh warga sekolah yaitu guru dan siswa. Sistemnya adalah menggunakan musyawarah dan voting. Hasil penelitian terkait dengan partisipasi aktif warga sekolah dalam perekrutan anggota OSIS menunjukkan bahwa sistem perekrutan melalui musyawarah. Kepala sekolah dan Pembina OSIS melaksanakan seleksi kepada calon pengurus OSIS serta melalui rekomendasi wali kelas dengan dilihat dari nilai akademik siswa. Sistem perekrutan tersebut tentunya ada kelebihan dan kekurangannya. Kelebihan dari sistem tersebut adalah lebih praktis, karena hanya melihat dari nilai akademik siswa. Kekurangan dari sistem tersebut adalah partisipasi siswa kurang dilibatkan, sehingga perekrutannya tidak bersifat sukarela. Temuan hasil penelitian terkait dengan pelaksanaan program kerja OSIS SMP Negeri 22 Semarang juga menunjukkan bahwa partisipasi aktif pengurus OSIS cukup baik. Artinya, seluruh pengurus OSIS selama ini selalu melaksanakan program kerja OSIS. Namun, tidak seluruh pengurus OSIS dapat berpartisipasi aktif dalam pelaksanaannya. Temuan tersebut sesuai dengan pendapat dari Siti (2011: 61) partisipasi dalam pelaksanaan adalah kelanjutan dalam rencana yang telah digagas sebelumnya yang meliputi penggerakan sumber daya, kegiatan administrasi, koordinasi, dan penjabaran program.

Hasil penelitian menunjukkan bahwa OSIS SMP Negeri 22 Semarang sudah berperan dalam membentuk keaktifan siswa. Partisipasi aktif 
siswa dapat dilihat dari keaktifan siswa di kelas dalam kegiatan belajar mengajar. Hasil temuan penelitian di lapangan juga menunjukkan bahwa pengurus OSIS mempublikasikan selebaran informasi (pamflet) melalui media sosial. Pamflet tersebut menginformasikan kegiatan penggalangan dana oleh pengurus OSIS kepada masyarakat sekitar yang terdampak Pandemi COVID19. Hasil dari pengumpulan donasi tersebut berupa barang maupun uang yang akan diberikan kepada masyarakat di sekitar SMP Negeri 22 Semarang yang terdampak Pandemi COVID-19. Temuan tersebut sesuai dengan pendapat dari Siti (2011: 61) partisipasi dalam pengambilan manfaat tidak lepas dari hasil pelaksanaan yang telah dicapai baik yang berkaitam dengan kualitas maupun kuantitas.

Evaluasi program kerja oleh OSIS SMP Negeri 22 Semarang dilaksanakan setiap tahun sekali bersama dengan kepala sekolah dan pembina OSIS. Selain itu, evaluasi juga dilaksanakan setiap selesai pelaksanaan program kerja dengan di dampingi pembina OSIS apabila diperlukan. Hasil penelitian menunjukkan bahwa partisipasi aktif pengurus OSIS baik. Antusias pengurus OSIS dapat dilihat dengan pelaksanaan musyawarah seluruh pengurus OSIS terlebih dahulu untuk mempersiapkan hasil evaluasinya kepada pembina OSIS dan kepala sekolah. Kemudian, pengurus OSIS menyampaikan hasil evaluasinya sesuai dengan bidang masing-masing. Temuan tersebut sesuai dengan pendapat dari Siti (2011: 61) partisipasi dalam evaluasi berkaitan dengan pelaksanaan program yang sudah direncanakan sebelumnya.

\section{PEMBAHASAN}

Pendidikan politik di Indonesia yang merupakan negara demokrasi erat kaitannya dalam membangun sikap demokratis. Hal tersebut sejalan dengan pendapat dari Kartini Kartono (1996: 57) yang menyatakan bahwa tujuan pendidikan politik adalah memberikan sumbangan besar bagi proses demokrasi yang semakin maju dari semua individu dan masyarakat dan dengan prinsipprinsip realistik, lebih manusiawi dan berlandaskan hukum formal dalam menggalang komunikasi politik. Penelitian ini mengacu pada Peraturan Menteri
Pendidikan Nasional Nomor 39 Tahun 2008 tentang Pembinaan Kesiswaan. Selain itu, penelitian ini juga berpedoman pada UndangUndang Republik Indonesia Nomor 20 Tahun 2003 tentang Sistem Pendidikan Nasional. Berdasarkan hasil penelitian di lapangan, OSIS sebagai salah satu organisasi kesiswaan di sekolah berperan dalam membangun sikap demokratis siswa. Sekolah juga berupaya memberikan pembinaan kepada pengurus OSIS melalui beberapa bentuk dalam membangun sikap demokratis siswa.

Salah satu tujuan pendidikan politik salah satunya adalah untuk membentuk kesadaran politik warga negara dan sadar akan hak dan kewajibannya sebagai warga negara. Oleh karena itu, perlu adanya partisipasi aktif dari setiap warga negara untuk merealisasikan tujuan tersebut dengan mencerminkan nilai demokrasi. Hal tersebut sejalan dengan pendapat dari Kartini Kartono (1996: 68) terkait dengan tujuan pendidikan politik dengan mengupayakan: (1) melaksanakan realisasi diri / aktualisasi diri dari dimensi sosialnya; (2) mengembangkan semua bakat dan kemampuannya (aspek kognitif, wawasan, kritis, sikap positif, keterampilan politik); (3) agar orang bisa aktif berpartisipasi dalam proses politik, demi pembangunan diri, masyarakat sekitar, bangsa, dan negara. Pemahaman dari tujuan pendidikan politik tersebut dapat di aplikasikan di lingkungan sekolah dengan ikut berpartisipasi aktif melalui organisasi kesiswaan, dalam hal ini adalah OSIS SMP Negeri 22 Semarang. Berdasarkan hasil penelitian di lapangan, partisipasi aktif siswa sebagai warga sekolah dapat dilihat dari pemilihan ketua dan wakil ketua OSIS serta perekrutan pengurus OSIS. Selain itu, partisipasi aktif pengurus OSIS dapat dilihat dari aktivitas dan proses organisasi.

\section{SIMPULAN}

Upaya sekolah dalam membangun sikap demokratis siswa adalah dengan memberikan pemahaman pendidikan politik. Pengurus OSIS sudah mengimplementasikan pemahaman tersebut dan dapat diketahui bahwa toleransi telah diimplementasikan oleh pengurus OSIS. 
Sekolah memberikan ruang untuk kebebasan berpendapat dan pengurus OSIS telah menggunakan haknya dalam bebas berpendapat. Pengurus OSIS dapat menunjukkan sikapnya dalam menghormati perbedaan pendapat. Pengurus OSIS dapat memahami keanekaragaman. Sekolah dengan pengurus OSIS dapat saling terbuka serta sekolah dengan pengurus OSIS dapat menunjukkan komunikasi yang baik. Pengurus OSIS dapat menunjukkan sikap santun dan sikap saling menghargai yang merupakan wujud dari menjunjung tinggi nilai dan martabat kemanusiaan. Sekolah berupaya dalam memberikan motivasi percaya diri serta pengurus OSIS dapat mengimplementasikan walaupun belum maksimal. Sekolah berupaya dalam memberikan motivasi sikap mandiri dan pengurus OSIS dapat menunjukkan sikap mandiri yang dapat diartikan sebagai tidak menggantungkan pada orang lain. Pengurus OSIS dapat menunjukkan sikap saling menghargai. Pengurus OSIS dalam mengutamakan kepentingan umum serta sopan santun kepada orang lain yang merupakan wujud dari mampu mengekang diri. Pengurus OSIS dapat menunjukkan kebersamaan serta dapat menjalankan tanggung jawabnya sesuai dengan peran.

Upaya sekolah dalam membangun partisipasi aktif siswa adalah dengan memberikan pemahaman dari tujuan pendidikan politik di lingkungan sekolah melalui realisasi partisipasi siswa dan pengurus OSIS. Partisipasi aktif siswa dapat dilihat melalui partisipasi aktif dalam pengambilan keputusan, partisipasi aktif dalam pelaksanaan, partisipasi aktif dalam pengambilan manfaat; dan partisipasi dalam evaluasi. Selain itu, sekolah juga memberikan pemahaman sikap sosial kepada pengurus OSIS sebagai bentuk dari partisipasi aktif pengurus OSIS dalam memahami kesadaran sosialnya yang dapat diketahui sebagai berikut. Komunikasi yang baik antara sekolah dengan pengurus OSIS, pengurus OSIS dapat menunjukkan sikap sosial yang lebih baik daripada siswa lainnya dan pengurus OSIS telah mengimplementasikan sikap sosial melalui program atau kegiatan yang dilaksanakan.

\section{DAFTAR PUSTAKA}

Depdiknas. 2003. Undang-Undang RI No. 20 tahun 2003 tentang sistem pendidikan nasional.

Hamdi, Ibrahim. 2019. Pembentukan Nilai-Nilai Demokrasi melalui Kegiatan Organisasi di Sekolah. Jurnal Vol 4(1). Serang: Universitas Sultan Ageng Tirtayasa.

Hamisa, Wilda. 2016. Peran Pendidikan Kewarganegaraan Sebagai Pendidikan Politik Dalam Membangun Sikap Demokratis dan Partisipasi Siswa dalam Organisasi Kesiswaan di SMA Muhammadiyah 5 Yogyakarta. S2 Tesis. Yogyakarta: Universitas Negeri Yogyakarta.

Hartatik, Yulianti. 2014. Implementasi Pendidikan Karakter di Kantin Kejujuran. Malang: Gunung Samudera.

Irene, Siti. 2011. Desentralisasi dan Partisipasi Masyarakat dalam Pendidikan. Yogyakarta: Pustaka Pelajar.

Kartono, Kartini. 1996. Pengantar Metodologi Riset Sosial. Bandung: Mandar Maju.

Lauster, Peter. 2002. Tes Kepribadian. Jakarta: Bumi Aksara.

Nurul Fajar, Wildan. 2015. Pelaksanaan Pendidikan Politik di Sekolah dalam Meningkatkan Kesadaran Politik Siswa. Jurnal. Purwokerto: Universitas Muhammadiyah Purwokerto.

Poerwadarminta. 2007. Kamus Umum Bahasa Indonesia. Jakarta: Balai Pustaka.

Rajafi, Ahmad. 2018. Khazanah Islam: Perjumpaan Kajian dengan Ilmu Sosial. Yogyakarta: CV Budi Utama.

Sugiyono. 2016. Metode Penelitian Pendidikan. Bandung: Alfabeta.

Sugiyono. 2017. Metode Penelitian Pendidikan Pendekatan Kuantitatif, Kualitatif, dan R\&D. Bandung: Alfabeta.

Sumarsono, H, R. 2017. Mengkritisi Aporisma Orang Jawa. Bekasi: Media Maxima.

Supardi. 2011. Dasar-dasar Ilmu Sosial. Yogyakarta: Ombak.

Taniredja, Tukiran. 2015. Konsep Dasar Pendidikan Kewarganegaraaan. Yogyakarta: Ombak.

Wu, S.I., Hung, J.M. 2008. A Performance Evaluation Model of CRM on Nonprofit Organizations. Journal Vol 19(4).

Zamroni, 2001. Pendidikan Untuk Demokrasi. Yogyakarta: Bilgraf Publising. 